Journal of Sustainability Perspectives

\title{
Holistic Approach for Creating Environmentally Friendly Campus
}

\author{
Andrey Andoko ${ }^{1,},{ }^{*}$ Niki Prastomo ${ }^{2}$ \\ ${ }^{1}$ Department of Informatics, Universitas Multimedia Nusantara (UMN), Jl. Scientia Boulevard, Gading Serpong, \\ Tangerang, Banten-15811 Indonesia \\ ${ }^{2}$ Department of Physics Engineering, Universitas Multimedia Nusantara (UMN), JI. Scientia Boulevard, Gading \\ Serpong, Tangerang, Banten-15811 Indonesia \\ * corresponding author: andrey@umn.ac.id
}

Article Info

Received:

15 March 2021

Accepted:

25 May 2021

Published:

1 June 2021

DOI:

https://doi.org/10.14710/i sp.2021.11753

\begin{abstract}
To achieve an environmentally friendly campus, UMN operates gas engine generator with co-generation system. Waste heat from generator powers absorption chiller for air conditioning. UMN benefits clean energy sources, reduced pollution, and energy saving. The next phases rely on energy consumption reduction by applying passive design. Two towers were designed with double-skin facade. The perforated aluminum panel reduces solar heat gain on the building wall while still allows sunlight into the room for natural lighting. Lower room temperature will reduce cooling load, which will save energy. Combined with energyefficient appliances and natural air ventilation for corridors and open space, this concept saves more than half of energy consumption. Both towers were awarded the first and second winners of ASEAN Energy Award in 2014 and 2019. Various trees have been planted and produce oxygen to supply fresh air to create comfortable studying environment without air conditioning. To reduce carbon footprint, UMN provides shuttle bus and bike-sharing service. A holistic approach is implemented by recycling and conserving water with sewage water treatment and infiltration wells surrounding the campus. As part of the sustainability program, UMN has also utilized solar energy.
\end{abstract}

\section{Keyword:}

Green campus, green buildings, energy efficiency, sustainability

\section{Introduction}

The world has been affected by climate change, and it is distressing more promptly than many expected. The warmest temperature on record, natural disasters that occur more intense, and unpredicted extreme weather throughout the world in 2019 are evidence. Global temperatures are anticipated to rise by at least $3^{\circ} \mathrm{C}$ towards the end of the century, which is double than the climate experts have warned as the limit to avoid the most severe economic, social and environmental consequences [1]. One of the significant factors that are risking the environment is the use of our energy resources. Since the establishment of the 
industrial age, the earth's temperature has risen. The carbon dioxide concentration has also increased in the atmosphere by $35 \%$ due to the increased use of fossil fuels [2].

One of the most vital technological challenges to overcome climate change issues is how to reduce energy demand. Since buildings provide a significant portion of global energy consumption, which in developed countries has steadily increased reaching figures between $20 \%$ and $40 \%$ for residential and commercial, we must be able to do something significant and make it one of the main efficiency savings targets $[3,4]$. Population growth affects the time spent inside buildings, the need for building services, and eventually increasing demand for comfort level. Assured, the rising trend in energy demand for HVAC and lightings will continue in the future [4].

The decision to build a green building, which is a practice of creating structures and using environmentally responsible and resource-efficient processes throughout a building's life cycle, is essential to be made as early as possible in the designing stage. This step provides opportunities for introducing technologies and design solutions to be more available and adjustable. As the project design and construction process progress, it can be costly to implement new ideas. Furthermore, some factors must be considered for the chosen green building technologies, i.e., the building's function, occupant comfort, budget and life-cycle cost, environmental impact, resources use efficiency, site and location, building materials, architecture, equipment choices, monitoring and control, and regulatory codes and certification [5].

Universitas Multimedia Nusantara (UMN), which carries the green campus concept to offer a comprehensive learning experience supported by complete facilities and a pleasant environment, has made many efforts and approaches to implement green building construction. This paper will show technically the holistic efforts that have been made by UMN in realizing an environmentally friendly campus environment. Two buildings will be reviewed: New Media Tower (NMT) and PK Ojong - Jakob Oetama Tower (PKO-JOT) (Fig. 1). Both towers were awarded the first and second winners of the ASEAN Energy Award in 2014 and 2019. Succeeding, UMN will perform additional efforts to obtain green building certification.

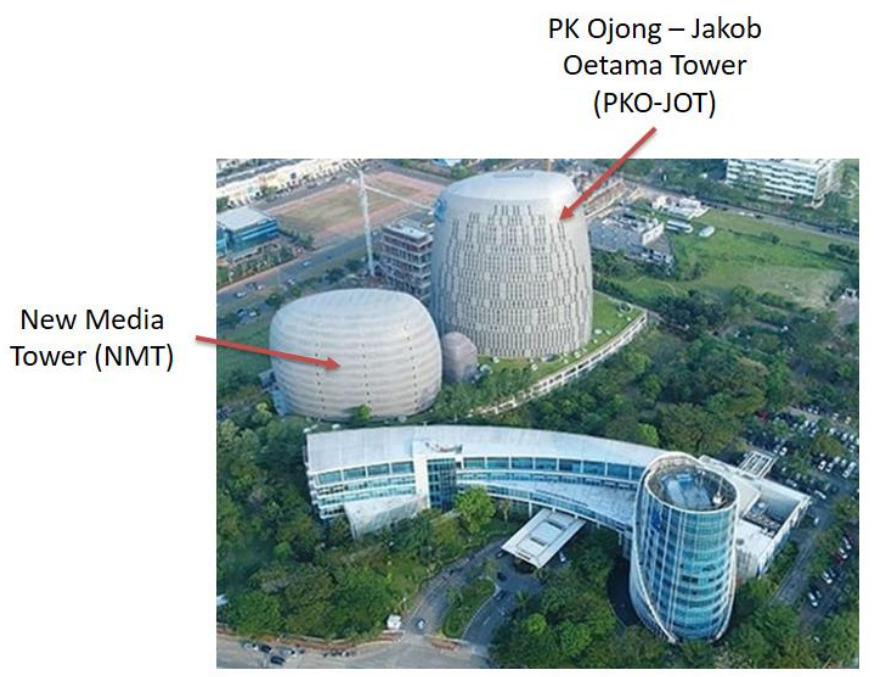

Figure 1. Universitas Multimedia Nusantara (UMN) Campus Area. 


\section{Holistic Approach}

Building energy consumption in Indonesia is mostly used for the HVAC system (for about $47 \%$ to $65 \%$ ). Then, the consumption lighting load contributes $15 \%$ to $25 \%$ of the total energy consumption. Therefore, energy efficiency strategies and approaches to reduce HVAC and lighting energy consumption should be incorporated into all aspects of the building through passive and active design technologies [6].

Since the beginning, UMN was designed as a campus that is environmentally friendly and energy efficient. UMN has a land area of 8 hectares with a floor area of 95,000 m2, and the number of active students is 8,000 people. UMN provides a shuttle bus, bike-sharing service, and utilization of solar-powered streetlight to reduce carbon footprint. The energyefficient building was planned and constructed starting from the early stage.

To give the right comfort level for all residents while delivering an energy-efficient concept, UMN simulated the building model using EnergyPlus. Simulations with data input of solar path of the sun, historical weather data, amount of people in the classrooms, and amount of heat from each light were conducted. Firstly, a building model was constructed and then tested to know how much energy it uses over the full year. Then make changes to the model of the building until the energy use of the building optimized.

Energy modeling and simulations tools allow the designer to evaluate the energy performance of the building. The virtual environment considered the building's geometrical model, design parameters, occupancy schedules, and local weather conditions. The building's energy consumption that simulated at time intervals is a typical output of energy modeling. The data later being used as a tool to compare and contrast various energyefficient technologies for the building at the design stage and cost implications [5].

Fig. 2 shows the lighting simulation results. Because natural lighting is the healthiest type of light, as much natural light into the building as possible while still being very careful to keep the cooling costs down, the illumination value of a minimum of 250 lux was achieved by design, accommodate the Indonesian National Standard for energy conservation in lighting systems for classroom [7].
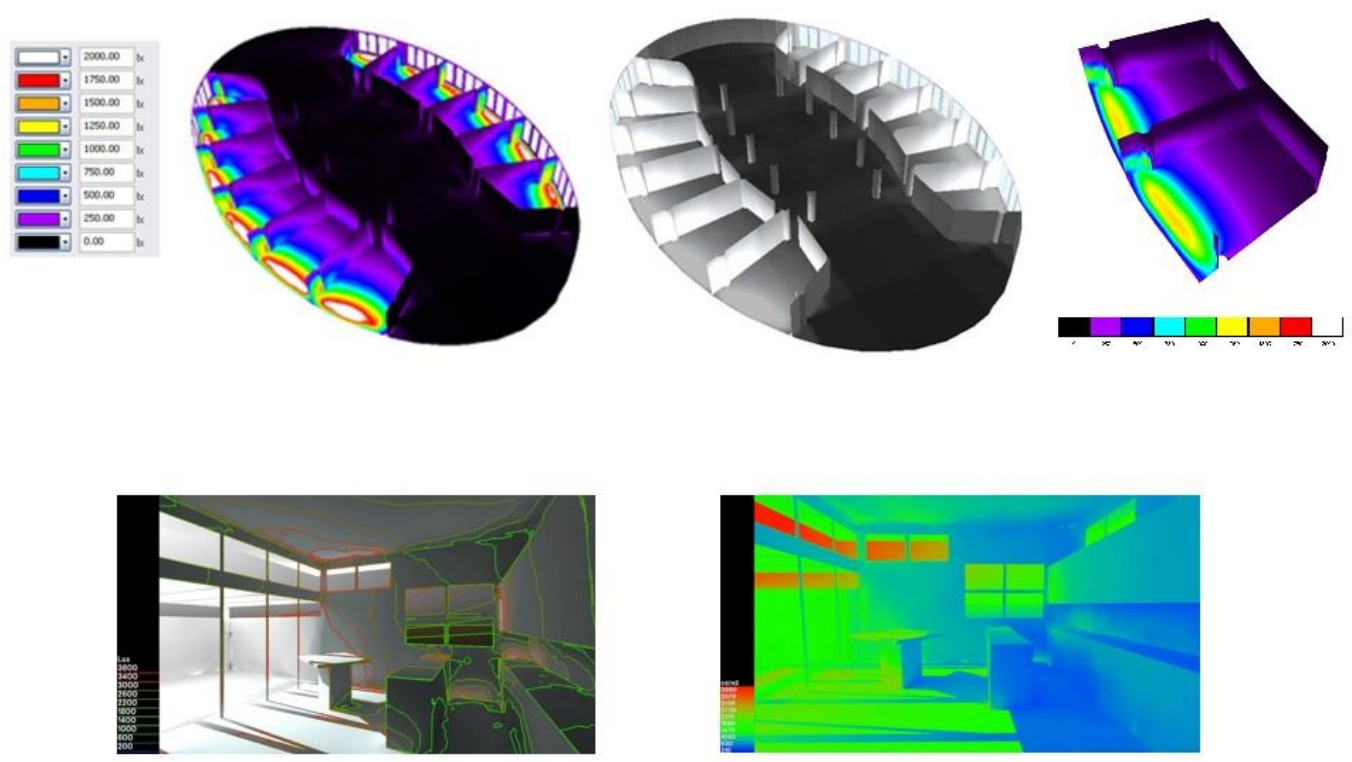

Figure 2. Lighting simulation of NMT builiding. 


\section{a. Passive Design}

Building Orientation. The orientation of the NMT and PKO-JOT buildings, slightly east to west, has been chosen to minimize solar heat gain based on solar radiometry simulations. The west and eastern sides of the building are used as a service area (the elevator and toilet), while the north and south sides are mostly used for classrooms, laboratories, and offices.

Double Skin Façade. NMT and PKO-JOT buildings have integrated a double skin façade, and it becomes the most prominent feature. In a double-skin façade, there is a median gap between the two skins that can provide an area for air to flow. The gap itself can be ventilated through mechanical mechanisms or by natural air circulation. Hot air can be vented out through the cavity to reduce solar gain in a warm climate, leading to the reduced cooling load. Whether in colder climates, the heat gained from solar energy can be trapped and circulated to the interior space for heating [5]. A further advantage of the double-skin façade is that the internal structure is more protected to weather conditions [8].

Double skin facade set 1 meter away from room glass window to maximize the use of air gap as an insulator and air circulation (Fig. 3). The inside room is already comfortable enough for activities. The air condition will be set to produce higher temperature air than usual, which can save energy. This space also serves as for maintenance and cleaning windows and skin. The façade was made from the perforated aluminum panel. The pores were designed with a specific pattern to maximize solar heat gain reduction. Most of the pore's positions are about the same level as glass windows to maximize sunlight going into natural lighting rooms.

Calculations in the field show that when the outside air is at $31^{\circ} \mathrm{C}$, the aluminum panels successfully reflect sunlight. As the results, the temperature in the double-skin gap area to be $28^{\circ} \mathrm{C}$ while indoors is $26^{\circ} \mathrm{C}$. These results provide an opportunity for residents in the room to feel comfortable even though they are not using the Air Conditioning system. Energy simmulation shows that the double skin façade reduced the amount of heat coming through the windows by more than $70 \%$.
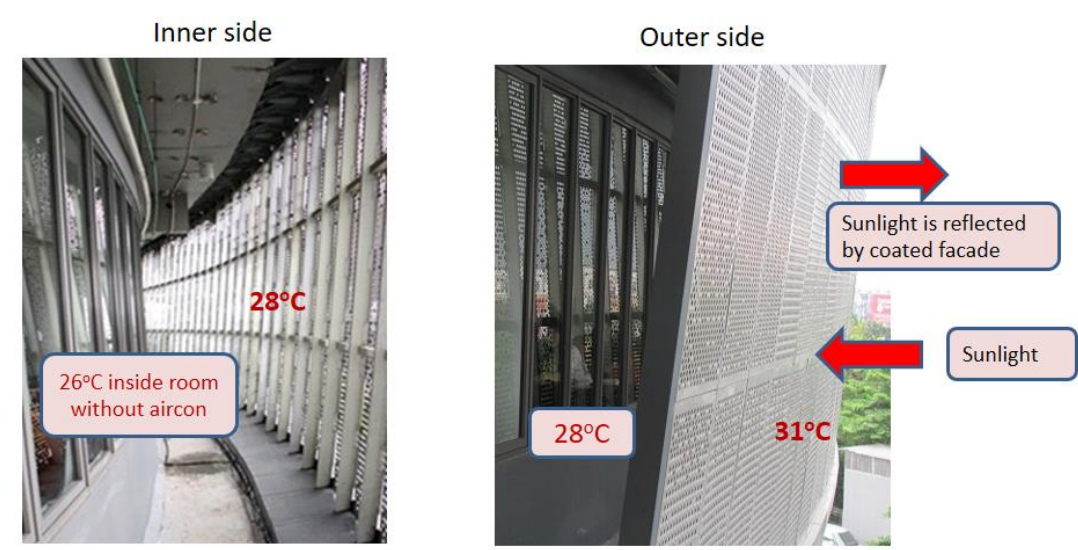

Figure 3. Inner and outer side of double façade system.

Natural Ventilation. NMT and PKO-JOT buildings maximize natural ventilation to reduce air conditioning consumption, applied to the basement area, which is used as parking space and workshop, first floor, entire corridor, and top floor. Uses the "Stack effect" to initiate air ventilation, driven by the thermal and pressure differences between the bottom 
and top of the solar chimneys (Fig. 4). No electrical exhaust fan installed. NMT building has four chimneys for natural ventilation for the semi-basement parking area (4.091 m2).

Performs on a similar principle as the Trombe wall, the chimney enhances natural ventilation using the air's buoyancy. The air trapped inside the column was warmed by solar heat gain, causing it to rise. As a result, new outside air is pulled through the building, ventilate, and cool the building below. The chimney head should be higher than the roof level and facing the sun directly to have effectively functioned as natural ventilation [5].

From the second floor and above, passive ventilation in the open corridors between the classrooms eliminates air conditioning in these areas. The air flows from the façade pores through space (cross ventilation) (Fig. 5(a)). The first floor used for the canteen and student activity center is designed with an open space concept so that the air will circulate across all areas. It accommodates up to 1,200 seats. The entire first floor is comfortable enough without air conditioning and has an average airflow: $2.87 \mathrm{~m} / \mathrm{s}$ (Fig. 5(b)). The corridor occupies approximately $24 \%$ of the total floor area. By removing mechanical cooling from these areas, the cooling load on these floors is reduced by $24 \%$. Airflow at corridor area is $4.01 \mathrm{~m} / \mathrm{s}$ (Fig. 5(c)).

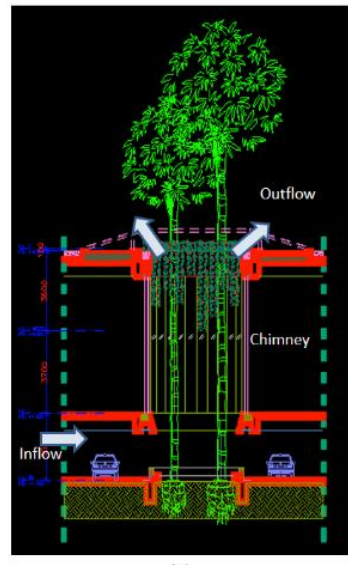

(a)
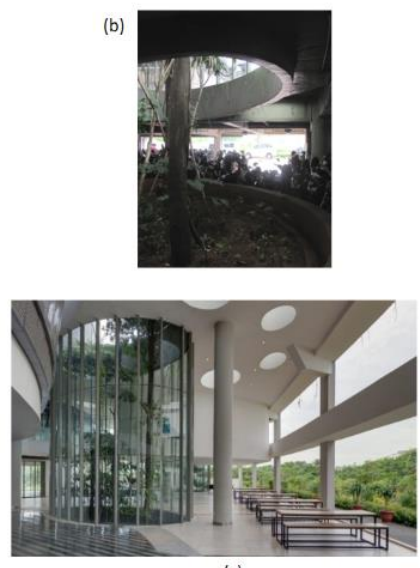

(c)

Figure 4. (a) Chimneys as Natural Ventilation system. (b) Chimnyes basement view.

(c) Chimneys lobby view.

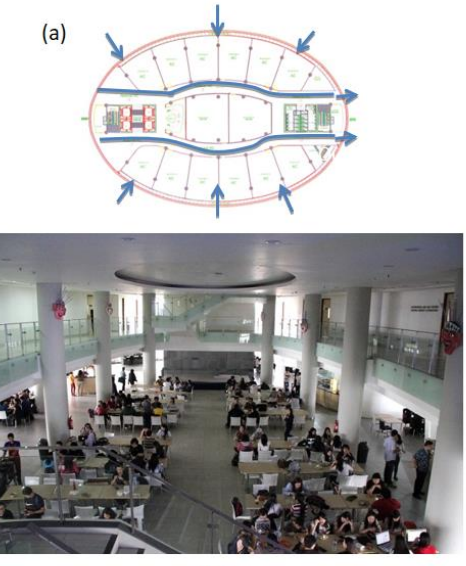

(b)

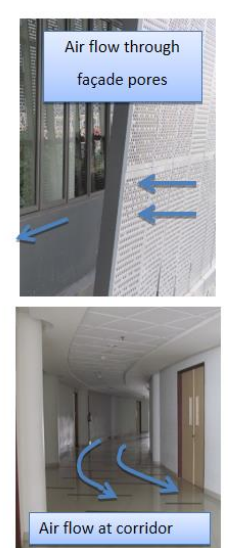

(c)

Figure 5. (a) Air flows through façade pores. (b) Cross ventilation system at Canteen area. (c) Air flow at coridor. 
Wall Material. To reduce thermal bridging, the buildings are utilizing M-system walls. Polystyrene materials that are modified as load-bearing elements are used in this technology. Modifications made include providing a high-quality wire mesh frame and coating the polystyrene with a relatively thin layer of plaster. The result is that the structural elements are almost similar to the load-bearing walls [9]. The technology also functions as sound insulation from outside noise disturbance. They are applied to all walls, except structural walls.

Natural Lighting. Natural lighting is maximized to save energy costs by eliminating the need for artificial lighting, and also as a strategy to improve health and wellbeing. Natural lighting is important to enhance the quality of the light environment. It can improve visual comfort while saving energy consumption [10]. All the walls, floors, and ceilings are painted with bright colors to reflect light to maximize natural light. More than $80 \%$ of building space uses natural daylighting.

Sustainable Landscape. To maximize the comfortable environment from air circulation, NMT and PKO-JOT buildings are surrounded by trees as a source of oxygen and reduces air temperature. They are developing the campus concept in the "jungle" with the choice of trees and botanical garden atmosphere, including trees inside the building. Roof Garden also provided at NMT, dedicated to Business Incubator Skystar Ventures (Fig. 6). Several functions of an eco-roof are serving to blend the building to the environment, support climatic balance, and aesthetic feature [11].

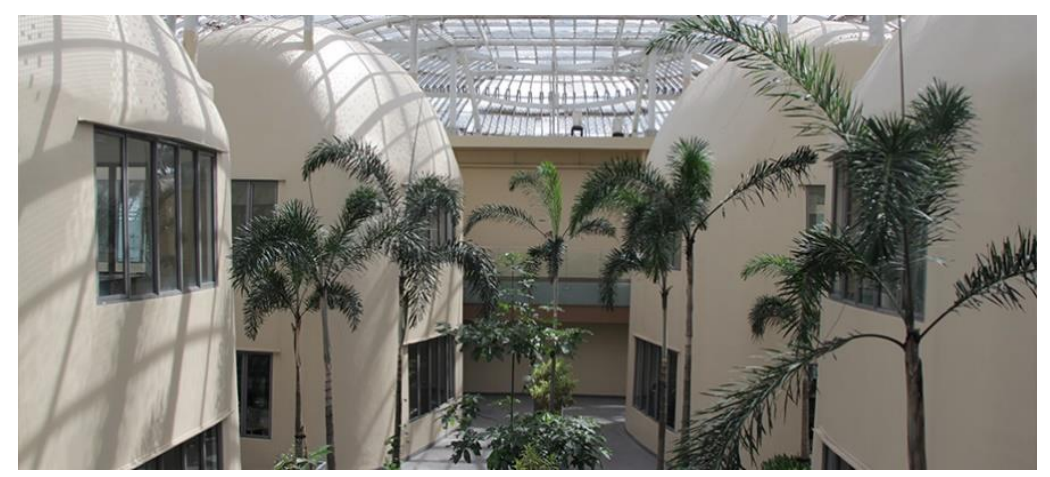

Figure 6. Roof garden at NMT dedicated for Business Incubator Skystar Ventures.

\section{b. Active Design}

Air Conditioning (Refrigerant, Pump, and Motors). The cooling system at UMN uses environmentally friendly chiller with refrigerant $\mathrm{R}-134 \mathrm{~A}$. The installation of variable speed drives (VSD) reduces the energy consumption of pumps and motors and increases the life of the machinery. Enhancement of chiller plant load efficiency can be achieved by lowering condenser water temperatures of a specific chiller, utilization of variable-speed drive for the compressor motor, and operating conditions that are analyzed to determine the number and size of chillers. Furthermore, by adjusting the pumps' capacity based on the actual pressure drop and peak water flow through each component in the system, energy use in the pumping system can be constrained [9].

Lighting. UMN apply light-emitting diodes (LEDs) lamps with electronic ballast for lighting purpose. LED bulbs are the latest addition to the list of energy-efficient light sources. The emitted light was the form of released energy of a combination process between electrons and holes when electrical current passes through a semiconductor material. 
Compared with incandescent bulbs, LED use $75-80 \%$ less electricity and 25 times longer lifespan [5]. In terms of efficacy, LED provides up to $200 \mathrm{~lm} / \mathrm{W}$, compared to about $52 \mathrm{Im} / \mathrm{W}$ for incandescent bulbs, 80 to $93 \mathrm{~lm} / \mathrm{W}$ for linear fluorescent lights produce, and $65 \mathrm{~lm} / \mathrm{W}$ for compact fluorescent light bulbs. LEDs are also durable because it can absorb large shocks without malfunctioning [11]. As part of the sustainability program, UMN has also utilized solar energy. It increased the use of Renewable Energy used for street lighting.

Water Management. To conserve water, NMT and PKO-JOT Buildings recycle wastewater from any sources processed in the sewage water treatment (STP) unit in the basement. Recycled water is used for flushing toilets, watering plants, and water-cooling tower make-up. In green construction, water efficiency and conservation become more critical. Water sources are becoming scarce every year, while buildings consume $20 \%$ of water reserves. Technology development and implementation to provide better quality building work, but less water consumption needs to be done [12].

\section{Summary Remarks}

UMN continues to be committed to creating a campus that supports environmental sustainability. Energy-efficient utilization is the primary indicator of this achievement. With a holistic approach, detailed, structured design from the early stage of the campus building construction, UMN successfully gets the promising results. Based on the 2019 electricity consumption index, the campus building consumes $200 \mathrm{kWh} / \mathrm{m}^{2} /$ year. NMT building only consumes $66 \mathrm{kWh} / \mathrm{m}^{2} /$ year, while PKO-JKT consumes $61.18 \mathrm{kwh} / \mathrm{m}^{2} /$ year.

\section{References}

1. The Global Risk Report, 2020. World Economic Forum's Global Risks Initiative. Available online at https://www.weforum.org/reports/the-global-risks-report-2020, accessed on 17 August 2020

2. Hinrichs, R.A., Kleinbach, M., 2013. Energy: Its Use and the Environment, 5th Ed. Brooks/Cole Cengage Learning, Boston

3. Reynolds, J., Rezgui, Y., Hippolyte, J.L., 2017. Upscaling energy control from building to districts: Current limitations and future perspectives. Sustainable Cities and Society, Volume 35, pp. 816-829

4. Pérez-Lombard, L., Ortiz, J., Pout, C., 2008. A Review on Buildings Energy Consumption Information. Energy and Buildings. Volume 40 (3), pp. 394-398

5. Jadhav, N.Y., 2016. Green and Smart Buildings Advanced Technology Options. Springer Science+Business Media, Singapore

6. Jakarta Green Building User Guide Vol. 1 Building Envelope, 2012. Jakarta Green Building. Available online at https://greenbuilding.jakarta.go.id/files/userguides/Vol-1BuildingEnvelope-UserGuide.pdf, accessed on 17 August 2020.

7. Indonesian National Standard (SNI) 03-6197-2000, 2000. Indonesian National Standard.

8. Pérez, G., Coma, J., Martorell, I., Cabeza, L.F., 2014. Vertical Greenery Systems (VGS) for energy saving in buildings: A review. Renewable and Sustainable Energy Reviews. Volume 39, pp. 139-165

9. Suzaeni, 2013. Analysis Comparison of Lightweight Concrete Wall with M-System Wall (Case Study Providentia Dei Dormitory Project). Extrapolasi Jurnal Teknik Sipil Untag Surabaya, Volume 6 (1), pp. $8-17$

10. Zhua, T., Li, R., Li, C., 2017. The Analysis of Natural Lighting Simulation and Study on Energy Saving in Cigarette Factory. Procedia Engineering. Volume 205, pp. 895-901 
11. Kibert, C.J., 2016. Sustainable Construction Green Building Design and Delivery Fourth Edition. John Wiley \& Sons, New Jersey

12. Vatalis, K.I. Manoliadis, O., Charalampides, G., Platias, S., Savvidis, S., 2013. Sustainability components affecting decisions for green building projects. Procedia Economics and Finance. Volume 5, pp. $747-756$ 